\title{
Severe Maternal Morbidity: post-traumatic suffering and social support
}

\author{
Morbidade Materna Grave: estresse pós-traumático e suporte social \\ Morbilidad Materna Grave: estrés postraumático y soporte social
}

\section{Mônica Silva Silveira', Ricardo Queiroz Gurgel', Íkaro Daniel de Carvalho Barreto", Larissa Paes Leme Galvão', Marlizete Maldonado Vargas"II}

' Universidade Federal de Sergipe. São Cristovão, Sergipe, Brazil.

"Universidade Federal Rural de Pernambuco. São Cristovão, Sergipe, Brazil.

"' Universidade Tiradentes. Aracaju, Sergipe, Brazil.

\begin{abstract}
How to cite this article:
Silveira MS, Gurgel RQ, Barreto IDC, Galvão LPL, Vargas MM. Severe Maternal Morbidity: post-traumatic suffering and social support. Rev Bras Enferm [Internet]. 2018;71(Suppl 5):2139-45.

[Thematic issue: Mental health] DOI: http://dx.doi.org/10.1590/0034-7167-2017-0271
\end{abstract}

Submission: 04-13-2017_Approval: 02-06-2018

ABSTRACT

Objective: To assess the relationship of post-traumatic stress symptoms and the perception of social support in women submitted to Severe Maternal Morbidity (SMM). Method: A prospective cohort study, with 549 women from public hospitals. The Impact of Events and Social Support scales were used. Results: Women with SMM were from the State countryside $(p=0.046)$, with low schooling $(p=0.039)$ and did not work $(p<0.001)$. They presented higher consumption of alcoholic beverages $(p<0.001)$, did not perform prenatal $(p<0.001)$, and were older $(28.15 \pm 28$ years). Women with SMM had higher mean values of avoidance behavior (24.32, SD: 4.16), intrusive thinking (18.28, SD: 3.80), lower social support (0.11, SD: 0.001) with large effect size and lower social support satisfaction (0.69; SD: 0.19), with small effect size. Conclusion: SMM is a differential and negative factor for women's mental health, and social support can favor their coping.

Descriptors: Morbidity; Maternal Health; Post-Traumatic Stress Disorders; Social Support; Obstetric Nursing.

\section{RESUMO}

Objetivo: Avaliar a relação de sintomas de estresse pós-traumático e a percepção do suporte social em mulheres submetidas à Morbidade Materna Grave (MMG). Método: Estudo de coorte prospectivo, com 549 mulheres de hospitais públicos. Foram utilizadas as escalas de Impacto de Eventos e de Suporte Social. Resultados: Mulheres com MMG eram oriundas do interior do estado $(p=0,046)$, com baixa escolaridade $(p=0,039)$ e não trabalhavam $(p<0,001)$. Apresentavam maior consumo de bebidas alcoólicas $(p<0,001)$, não realizaram pré-natal $(p<0,001)$, e eram mais velhas $(28,15 \pm 28$ anos). As mulheres com MMG tiveram maiores médias de comportamento de esquiva (24,32; DP: 4,16), pensamento intrusivo (18,28; DP: 3,80), menor suporte social $(0,11$; DP: 0,001) com tamanho de efeito grande e menor satisfação do suporte social (0,69; DP: 0,19), com tamanho de efeito pequeno. Conclusão: A MMG é um fator diferencial e negativo para a saúde mental das mulheres, e o apoio social pode favorecer o seu enfrentamento.

Descritores: Morbidade; Saúde Materna; Transtornos de Estresse Pós-Traumáticos; Apoio Social; Enfermagem Obstétrica.

\section{RESUMEN}

Objetivo: Evaluar la relación de síntomas de estrés postraumático y la percepción del soporte social en mujeres sometidas a la Morbilidad Materna Grave (MMG). Método: Estudio de corte prospectivo, con 549 mujeres de hospitales públicos. Se utilizaron las escalas de Impacto de Eventos y de Soporte Social. Resultados: las mujeres con MMG provenían del interior del estado ( $p$ $=0,046)$, con baja escolaridad $(p=0,039)$ y no trabajaban $(p<0,001)$. En el caso de las bebidas alcohólicas $(p<0,001)$, no realizaron prenatal $(p<0,001)$, y eran mayores $(28,15 \pm 28$ años). Las mujeres expuestas a la MMG tuvieron promedios más altos de comportamiento de esquiva $(24,32$, DP: 4,16), pensamiento intrusivo $(18,28$, DP: 3,80), menor soporte social $(0,11$, DP: 0,001$)$ con tamaño de efecto grande y menor satisfacción del soporte social $(0,69$, DP: 0,19$)$ con tamaño de efecto 
pequeño. Conclusión: La MMG es un factor diferencial y negativo para la salud mental de las mujeres, y el apoyo social puede favorecer su enfrentamiento.

Descriptores: Morbilidad; Salud Materna; Trastornos por Estrés Postraumático; Apoyo Social; Enfermería Obstétrica.

\section{CORRESPONDING AUTHOR Mônica Silva Silveira E-mail: mssdoutora@gmail.com}

\section{INTRODUCTION}

However, little is known about the impact on mental health of women who have experienced Severe Maternal Morbidity ${ }^{(1)}$. Studies on stress and sickness in the pregnancy-puerperal phase, and psychological consequences have been increasingly frequent in the world literature.

Many women who have traumatic experiences during pregnancy, childbirth, or the puerperium experience the risk of life-threatening complications of the Severe Maternal Morbidity, both for their lives and for their children, with negative consequences for physical and mental health, as well as medium and long term sequels $\mathrm{s}^{(2-3)}$.

Of the criteria for the definition and diagnosis of maternal morbidity, the approach referring to clinical, laboratory and management markers is highlighted. The World Health Organization (WHO) defines Near Miss Maternal (NM) as a serious life threat, near death, in pregnant women or women who have recently given birth, occurring in pregnancy, childbirth or in up to 42 days after the end of gestation. This condition may include pre and postpartum hemorrhage, sepsis, abortion complications, ectopic pregnancy, rupture of the uterus and other conditions of severe obstetric complications, HELL syndrome (involving hemolysis, elevated liver, liver enzymes and low platelets), and admission in an intensive care unit ${ }^{(4)}$.

The perception of women about the experience of Severe Maternal Morbidity is described as physically and emotionally distressing, which brings negative feelings and emotions. In general, the experience of Severe Maternal Morbidity in women can be characterized in three interrelated areas: personal assessment of the Severe Maternal Morbidity, immediate reaction to the event, in other words, physical conditions, interpretation and emotion produced, and negative or positive consequences of the experience ${ }^{(5)}$.

In this context, research brings the relationship between obstetric complications and the development of traumatic behavior $^{(1,5-6)}$. According to the Diagnostic and Statistical Manual of Mental Disorders (DSM-V) of the American Psychiatric Association $^{(6)}$, Post-traumatic Stress Disorder (PTSD) is characterized by the presence of the development of symptoms after exposure to stress situations in one or more events, or sources associated with their knowledge, behavioral change and intrusive memory ${ }^{(7)}$.

It is observed in the literature that the study of social support investigates how the various forms of help that the individual receives and/or perceives can influence the management of difficulties and the process of sickness. Therefore, their investigation becomes relevant, because it is considered a multidimensional construct, since social support can be perceived in several spheres of the individual's action, through the proximity and availability of relationships, in the pursuit of security as strategy of self-regulation against physical and psychological threats in situations involving risks, stress or conflict and fear. It is also observed the importance of positive and effective social support to deal with, avoid or delay the effects of stressful situations in obstetric complications and the confrontation of the health-disease process ${ }^{(8)}$.

Knowing the impact that the Severe Maternal Morbidity brings to the mental health of women becomes indispensable, since this result is relevant for the referral of care protocols that offer greater efficiency in maternal and child care.

\section{OBJECTIVE}

To assess the relationship between the development of posttraumatic stress symptoms and the perception of social support in women who survived the Severe Maternal Morbidity.

\section{METHOD}

\section{Ethical aspects}

This study complies with Resolution 466/2012 of the National Health Council (Conselho Nacional de Saúde) and was approved by the Ethics Committee on Research Involving Human Beings, Universidade Federal de Sergipe (UFS), with an approved opinion. All subjects were previously invited to participate and were informed about the objectives, risks and benefits of the study. Being aware they have signed the Informed Consent Form.

\section{Design, place and period of study}

This is a prospective cohort study comprised of a convenience sample, with women who have recently given birth of two reference hospitals for medium and high obstetric risk, respectively linked to the Brazilian Unified Health System (SUS- Sistema Único de Saúde), in Sergipe State, northeastern Brazil. The collections were carried out in a total period of twelve months.

\section{Population and sample}

The selection of exposed and non-exposed groups, the SMM was performed in hospitals during the immediate puerperium by a physician and specialist in gynecology and obstetrics, who undertook an active search through the registry book of hospital admission of the ward obstetrics, puerperal ward, medical records and clinical assessment to identify eligible participants.

The mothers exposed to maternal morbidity were included in the group exposed to SMM $(\mathrm{N}=277)$, who completed the current diagnostic criteria, according to the WHO Working Group on Mortality and Morbidity ${ }^{(4)}$, and the group not exposed to Severe Maternal Morbidity, $(N=272)$, women who have recently given birth without complication of serious obstetric complications, totaling 549 subjects. Participants who did not live in Sergipe State were excluded from the groups, those who were born with serious disabilities, who died, and/or those with medical restriction due to the severity of the case, because of these situations, they compromised the emotional state, and act as a confounding variable. 
To delimit the sample, the sample size was calculated considering the Impact of Events Scale (IES). According to the study by Chery ${ }^{\left({ }^{9}\right)}$, the standard deviation of teenage mothers for IES was 15.8, and the standard error was 1.714 for a sample of 85 patients. Thus, for an average difference of each point in the scale with a meaning of $1 \%$ and power of $99 \%$, it would take 255 participants per group.

\section{Study protocol}

Data collection was performed in three stages; the first, in the immediate puerperium of hospital maternities, with the objective of identifying the characteristics of each group. The consecutive steps were performed at a State referral hospital. The second stage was performed within 90 days of birth to identify the social support received by the woman who has recently given birth and at 120 days to identify the symptoms of post-traumatic stress, through avoidance and intrusion. The last two collections were carried out at the University Hospital of Sergipe (UH), or at a home visit, when the participant had no access to the site.

The protocol adopted was composed of three collection tools, namely: socio-demographic questionnaire, Social Support Questionnaire (SSQ-6) and the Impact of Event Scale (IES). In the sociodemographic questionnaire, clinical, obstetric and habits variables were identified; place of origin of the participant, capital or countryside, age, schooling, marital status, work, completion of prenatal care, considered complete with six visits, parity (primiparous, 1 or more children), use of alcoholic beverages and smoking.

The Social Support Questionnaire (SSQ-6) is composed of six items to assess the perceived social support dimensions (the subject perceives as available if they need it), with each question asking for a two-part answer. In the first, it refers to the number of sources/people on the list who provide support; perceived social support $(\mathrm{N})$ of each SSQ item, corresponding to nine possibilities, in addition to the "none" option. In the second part, the respondent indicates the degree of social satisfaction (S), using a Likert type scale, with six points ranging from dissatisfied (1) to very satisfied (2), for correction, sum the sources of the first factor, reproducing the simple mean, which is also applied to the second factor, obtaining two total scores ${ }^{(10)}$.

The Social Support Questionnaire was submitted to several studies to determine psychometric measures ${ }^{(11-13)}$. When applying the tool to a sample of 602 university students, Kronbach's alpha coefficient resulted in 0.97 for SSQ-N and 0.94 for SSQ-S. The test-retest reliability was 0.90 for the SSQ-N and 0.83 for the SSQ-S, indicating that the SSQ is a stable tool with high internal consistency. According to literature ${ }^{(10,14-15)}$, consistent evidence was found on the role of social support as a protector of stressful situations when support measures are related to the perceived availability of interpersonal resources that correspond to the needs present in stressful events.

The Impact of Event Scale (IES) consists of 15 items of selfreport, Likert type, which measures the presence of avoidance behavior and intrusive memory after traumatic situations, according to frequency attributes, never, rarely, sometimes and always. It was validated for the Brazilian population and the cut limit of 25 points was adopted ${ }^{(16)}$. The scale is applied to the general population and in the field of obstetrics, related to the experiences of childbirth ${ }^{(17)}$, its psychometric properties are satisfactory, and continued use is justified as a measure of avoidance and intrusion processes ${ }^{(18)}$.

The Impact of Event Scale (IES), a scale developed by Horowitz et al. ${ }^{(16)}$, presents as proposal the assessment of subjective stress related to life events, not being focused in a specific situation, but in the particular characteristics that involve such events. It is a brief scale, composed of only 15 items, divided into a subset connected to the intrusion (items 1, 4, 5, 6, 10, 11 and 14) and a focused subset of avoidance (items 2, 3, 7, 8, 9, 12, 13 and 15).

The Impact of Event Scale (IES), although it was developed prior to the formal introduction of post-traumatic stress disorder within the diagnostic literature, is used for its screening ${ }^{(19)}$. Studies with IES resulted in good internal consistency scores, with Cronbach's alpha coefficients from 0.81 to $0.96^{(20-22)}$, validity with $100 \%$ sensitivity and $78 \%$ specificity ${ }^{(23)}$.

\section{Analysis of results and statistics}

Data were analyzed using R Core Team 2016 software. The Significance Level adopted was $5 \%$. Categorical variables were described using simple and percentage frequencies. For the ordinal or continuous variables, the means and standard deviations were calculated. To assess the association between categorical variables, the Chi-Square Test was used; for the mean differences, the Mann-Whitney's Test; and to infer the magnitude of the differences between the means, we used the effect size ${ }^{(24)}$ eta2 $\left(\eta^{2}\right)$, which is considered small $\left(0.01 \leq \eta^{2}<0.06\right)$, medium $\left(0.06 \leq \eta^{2}<0,14\right)$ and large $\left(\eta^{2} \geq 0,14\right)$. The influence of the screening tools (IES and SSQ-6) in the collection stages was assessed using the Pearson correlation coefficient, and ANCOVA (Analysis of Covariance) was applied to analyze the correlation differences between the groups. Odds ratios and adjusted odds ratios were calculated by using logistic regression for the Severe Maternal Morbidity and socio-demographic variables.

\section{RESULTS}

In this study, the results showed that participants with Severe Maternal Morbidity were mostly from cities in the State countryside $(p=0.046)$, with low schooling level $(p=0.039)$ and did not work $(p<0.001)$. In addition, they had a higher prevalence of alcohol consumption $(p<0.001)$, did not perform prenatal $(p<0.001)$, and were older $(28.15 \pm 28$ years $(p=0.038)$ than women (Table 1). The results of this study are presented in Table 1.

It was observed that women with less than 35 years of age (OR: 1.72; 95\% Cl: 1.11-2.65), who did not work (OR: 2.36; 95\% Cl: 1.53-3 (OR: 10.9, 95\% Cl: 3.28-36.1) and use alcoholic beverage (OR: 4.35, 95\% Cl: 2.66-7.11) have a greater chance of having Severe Maternal Morbidity, as indicated by the logistic regression results. (Table 1).

According to the Impact of Events Scale related to the behavior of avoidance and intrusion, and to social support in women with SMM, greater means of avoidance behavior were identified (24,32; SD: 4, 16; $\mathrm{p}\left(\mathrm{P}<0.001, \eta^{2}=0.895\right)$, and intrusive thinking (18.28, SD: $\left.3.80, p<0.001 ; \eta^{2}=0.763\right)$, lower social support $\left(0.11, S D: 0.001, p<0.001, \eta^{2}=0.151\right)$ with large effect size and lower social support satisfaction (0.69, SD: 0.19, $p=0.010$, $\eta^{2}=0.014$ ) with small effect size (Table 2). 
Table 1 - Socio-demographic, clinical, obstetric characterization and social habits of the sample of women with and without Severe Maternal Morbidity (SMM), Sergipe State, Brazil, 2013

\begin{tabular}{|c|c|c|c|c|c|c|}
\hline \multirow{3}{*}{ Variables } & \multicolumn{2}{|c|}{ Groups } & \multirow{3}{*}{$X^{2}$ (p value) } & \multirow{3}{*}{ OR (IC95) } & \multirow{3}{*}{ Adjusted OR (IC95) } & \multirow{3}{*}{$p$ value } \\
\hline & With SMM $(n=277)$ & Without SMM $(n=272)$ & & & & \\
\hline & n (\%) & n (\%) & & & & \\
\hline \multicolumn{7}{|l|}{ Origin } \\
\hline Capital & $95(34)$ & $200(74)$ & $3.971(0.046)$ & $1.45(1.01-2.09)$ & & \\
\hline Countryside & $182(66)$ & $72(26)$ & & 1 & & \\
\hline Average Age (SD) & $28.15(7.75)$ & $26.77(7.75)$ & $0.038^{*}$ & & & \\
\hline$\geq 35$ & 70 (25) & $53(20)$ & $2.64(0.104)$ & $1.40(0.93-2.09)$ & $1.72(1.11-2.65)$ & 0.104 \\
\hline$<35$ & $207(75)$ & $219(80)$ & & 1 & 1 & \\
\hline \multicolumn{7}{|l|}{ Schooling } \\
\hline$<8$ years & $198(53.5)$ & $172(46.5)$ & $4.246(0.039)$ & $1.46(1.02-2.09)$ & & \\
\hline$\geq 8$ years & $79(44.1)$ & $100(55.9)$ & & 1 & & \\
\hline \multicolumn{7}{|l|}{ Marital Status } \\
\hline Single & $59(21)$ & $75(28)$ & $2.928(0.087)$ & $0.71(0.48-1.05)$ & & \\
\hline Married & $218(79)$ & $197(72)$ & & 1 & & \\
\hline \multicolumn{7}{|l|}{ Work } \\
\hline No & $222(80)$ & $185(68)$ & $10.530(<0.001)$ & $1.90(1.28-2.80)$ & $2.36(1.53-3.62)$ & $<0.001$ \\
\hline Yes & $55(20)$ & $87(32)$ & & 1 & 1 & \\
\hline \multicolumn{7}{|l|}{ Prenatal } \\
\hline No & $26(9)$ & $3(1)$ & $18.820(<0.001)$ & $9.29(2.78-31.1)$ & $10.9(3.28-36.1)$ & $<0.001$ \\
\hline Yes & $251(91)$ & $269(99)$ & & 1 & 1 & \\
\hline \multicolumn{7}{|l|}{ Parity } \\
\hline Primipara & $43(16)$ & $32(12)$ & $1.644(0.200)$ & $1.34(0.82-2.20)$ & & \\
\hline 1 or more births & $234(84)$ & $240(88)$ & & 1 & & \\
\hline \multicolumn{7}{|l|}{ Alcoholic beverages } \\
\hline No & 192(69) & $243(89)$ & $33.445(<0.001)$ & 1 & 1 & \\
\hline Yes & $85(31)$ & $29(11)$ & & $3.65(2.30-5.79)$ & $4.35(2.66-7.11)$ & $<0.001$ \\
\hline \multicolumn{7}{|l|}{ Smoking } \\
\hline No & $261(94)$ & $263(97)$ & $1.922(0.166)$ & 1 & & \\
\hline Yes & 16(6) & $9(3)$ & & $1.79(0.78-4.13)$ & & \\
\hline
\end{tabular}

Note: SMM = Severe Maternal Morbidity; X2 = Chi-Square Test Statistics; * Mann-Whitney' Test; SD = Standard Deviation; OR = Odds Ratio; CI = Confidence Interval $=95 \%$.

Table 2 - Comparison between means and Standard Deviations (SD) of the sample of women with and without Severe Maternal Morbidity (SMM), Impact of Events Scale (IES) and Social Support (SSQ-6), Sergipe State, Brazil, 2013

\begin{tabular}{|c|c|c|c|c|}
\hline \multirow{3}{*}{ Variables } & \multicolumn{2}{|c|}{ Groups } & \multirow{3}{*}{$\begin{array}{c}\text { Mann- } \\
\text { Whitney }\end{array}$} & \multirow{3}{*}{$\mathrm{Eta}^{2}$} \\
\hline & $\begin{array}{l}\text { With } \\
\text { SMM }\end{array}$ & $\begin{array}{c}\text { Without } \\
\text { SMM }\end{array}$ & & \\
\hline & Mean (SD) & Mean (SD) & & \\
\hline \multicolumn{5}{|l|}{ Impact of events } \\
\hline Avoidance behavior & $24.32(4.16)$ & $5.10(2.08)$ & $<0.001$ & 0.895 \\
\hline Intrusive memory & $18.28(3.80)$ & $7.47(1.91)$ & $<0.001$ & 0.763 \\
\hline \multicolumn{5}{|l|}{ SSQ-6 } \\
\hline SSQ-N & $0.11(0.001)$ & $0.13(0.04)$ & $<0.001$ & 0.151 \\
\hline SSQ-S & $0.69(0.19)$ & $0.73(0.17)$ & 0.01 & 0.014 \\
\hline
\end{tabular}

Notes: $S D=S M M=$ Severe Maternal Morbidity; $S D=$ Standard Deviation; MannWhitney' Test; Eta ${ }^{2}=$ Effect Size; SSQ-N = Number of Sources/ Social Support People; SSQ-S = Satisfaction with the Support.

Regarding the correlation between the number of sources/people who provide social support (SSQ-N) and satisfaction of perceived support (SSQ-S) with avoidance or intrusion behaviors in the Impact of Events scale, no significant correlations were found group with
Severe Maternal Morbidity and in the group without this condition, as observed in the Pearson correlations. In addition, there is no difference in the correlations when comparing the groups, as pointed out in the Analysis of Covariance (Table 3).

Table 3 - Analysis of Covariance of the sample of women with and without Severe Maternal Morbidity (SMM) between Social Support (SSQ-6) and Impact of Events Scale (IES), Sergipe State, Brazil, 2013

\begin{tabular}{lcc}
\hline Variables & $\begin{array}{c}\text { SSQ-N } \\
\mathbf{R}(\boldsymbol{p} \text { value })\end{array}$ & $\begin{array}{c}\text { SSQ-S } \\
\mathbf{R}(\boldsymbol{p} \text { value })\end{array}$ \\
\hline Impact of events & & \\
Avoidance behavior & & \\
With SMM & $-0,034(0,577)$ & $0,088(0,144)$ \\
Without SMM & $-0,031(0,613)$ & $0,125(0,040)$ \\
F ( $p$ value) & $0,48(0,488)$ & $0,058(0,810)$ \\
Intrusive memory & & \\
With SMM & $-0,084(0,164)$ & $0,024(0,687)$ \\
Without SMM & $-0,084(0,167)$ & $0,070(0,251)$ \\
F ( $p$ value) & $2,99(0,084)$ & $0,04(0,832)$ \\
\hline
\end{tabular}

Note: SMM = Severe Maternal Morbidity; F = F-Test Statistics; SSQ-N = Number of Sources/ Social Support People; SSQ-S = Satisfaction with the Support. 


\section{DISCUSSION}

Some socio-demographic variables were found in women with Severe Maternal Morbidity, showing a lower schooling level, lower insertion in the labor market, lower frequency of prenatal follow-up and higher consumption of alcoholic beverages. These characteristics are consistent with the less favored social context, similar to other studies on the profile of women with Severe Maternal Morbidity(25-26).

The analyses of this study evidenced that the traumatic behavior of avoidance and intrusive memory was significantly higher in the situation of Severe Maternal Morbidity, with a higher risk of symptoms to develop the post-traumatic stress disorder. In another study of women experiencing imminent life-threatening pregnancy-related traumatic births, it was shown that many women could not erase from their memories morbid negative feelings, flashbacks, and nightmares associated with this period of their lives, and that the consequences of this negatively affected the physical and psychological well-being, and even the relationship of bonding with the babies ${ }^{(1,3)}$.

This is a qualitative study carried out in Brazil revealed, through the narratives of women who had experienced Severe Maternal Morbidity, emotional reactions from intrusive memory, imminent death, fear of harm to the baby, and guilt and frustration at the expectations of motherhood ${ }^{(27)}$. In qualitative international research with meta-ethnography, it was identified that the consequences of the suffering caused by Severe Maternal Morbidity were focused on clinical and psychological aspects, many of which resulted from periods of long hospitalization, loss of family life, lack of personal independence, and difficulties in fully exercising maternity ${ }^{(5,28)}$.

Through the results of this study, it can be suggested that the situation of Severe Maternal Morbidity makes women more vulnerable to changes in their emotional and psychological state, which can lead to the development of post-traumatic stress. In this sense, other studies emphasize that expectations and experiences related to motherhood are instigated by the desires and idealizations of the representation of being a mother. In the face of the aggravated sickness are often taken by the imminent fear of death, ambivalent feelings, provoking frustration, tension, anxiety and anguish and psychological sickness in women ${ }^{(5,299}$.

A prospective cohort study identified a prevalence of $8.4 \%$ in avoidance and $6.4 \%$ in intrusion, in the traumatic behavior of women with Severe Maternal Morbidity in the postpartum period $^{(30)}$. Other studies have also found a positive relationship between complications in pregnancy and/or childbirth and partial or total symptoms of post-traumatic stress disorder and avoidance and intrusion behavior ${ }^{(9,31-32)}$.

As for the aspects of the relationship between Severe Maternal Morbidity and perceived social support in women with SMM, there was a smaller source of social support, that is, fewer available people from whom women could receive support, and lower levels of satisfaction with the perceived support, compared to the group without the situation of severe morbidity.

The low rate of positive perception of social support and the level of perceived satisfaction can have damaging consequences for mothers on physical and psychological health. It is evident that social support networks and family support are of fundamental importance in maintaining mental health and coping with stressful circumstances, and can act as a buffer against the effects of the sickness ${ }^{(10)}$. In this sense, the availability and accessibility of high quality health care, broad social support networks, personal characteristics and pre-existing health conditions will influence the coping with Severe Maternal Morbidity ${ }^{(5)}$.

Studies have associated social support and health levels, functioning as a "protective" agent, when positive, against the risk of diseases caused by stress, or, when negative, exerts a moderating effect of aggravations. The coping effort in having social support may minimize or prevent negative emotional, behavioral, cognitive and physiological responses to their stressors ${ }^{(8)}$.

In this study, there was no significant statistical difference in the results regarding the association between the traumatic behavior of avoidance and intrusion and social support. However, consideration should be given to the possibility of a complex interaction of these variables, which may have interfered with their outcome, such as individual personality factors, previous history, environmental aspects and individual psychodynamic aspects ${ }^{(33)}$. Some situations with previous traumatic events, childhood adversities, genetic and physiological aspects, and peritraumatic events such as magnitude of trauma, inappropriate coping strategies, environmental and subsequent social adversities ${ }^{(7)}$.

\section{Study limitations}

As limitations of the study, we can mention the lack of qualitative data of the participants that could corroborate with the findings, in order to reveal more explicitly the experience regarding Severe Maternal Morbidity and the development of symptoms of posttraumatic stress, verified in the outcome of this study. However, the limitations cited do not compromise the results obtained regarding the relevance of the presented theme, proving to be indicative of the need for actions and coping strategies that favor programs and public policies on the specificities of this population.

\section{Contributions to the sectors of Nursing, Health or Public Policy}

This study aims to contribute to the improvement in the care process and assistance of health professionals, especially to the nurse, in order to qualify their listening, with a view to health promotion, prevention and integrality of actions directed at Primary Care and early identification of risks to maternal and child health in the context of public policies.

\section{CONCLUSION}

The situation of Severe Maternal Morbidity was decisive as a differential experience between the groups, since it was a singular moment in women's life, with potential risk and disturbing consequences. Mental health is undoubtedly the key pillar of maternal and child care and should be properly valued in this process, which is to offer women appropriate and multidisciplinary care in the puerperium.

Therefore, knowing the processes that deteriorate mental health in severe morbidity goes beyond limits of clinical knowledge and gives attention to decisive relationships of psychological and social contribution, maternal-fetal care and positive development of family relationships. It is concluded, therefore, that Severe Maternal Morbidity negatively impacts on the women's mental health, provoking behavior of avoidance and intrusion, demanding of the woman the strengthening of the familiar and social bonds for its confrontation. 


\section{REFERENCES}

1. Furuta M, Sandall J, Bick D. A systematic review of the relationship between severe maternal morbidity and post-traumatic stress disorder. BMC Pregnancy Childbirth[Internet]. 2012[cited 2016 Dec 20];2:125. Available from: http://dx.doi.org/10.1186/1471-2393-12-125

2. Firoz T, Chou D, Von Dadelszen P, Agrawal P, Vanderkruik R, Tunçalp O, et al. Measuring maternal health: focus on maternal morbidity. Bull World Health Organ[Internet]. 2013[cited 2016 Jan 10];91(10):794-6. Available from: http://dx.doi.org/10.2471/ BLT.13.117564

3. Elmir R, Schmied V, Wilkes L, Jackson D. Women's perceptions and experiences of a traumatic birth: a meta-ethnography. J Adv Nurs[Internet]. 2010[cited 2016 Dec 20];66:2142-53. Available from: http://dx.doi.org/10.1111/j.1365-2648.2010.05391.x

4. Say L, Souza JP, Pattinson RC. WHO Working Group on Maternal Mortality and Morbidity classifications. Maternal near miss towards a standard tool for monitoring quality of maternal health care. Best Pract Res Clin Obstet Gynaecol[Internet]. 2009[cited 2016 Dec 20];23(3):287-96. Available from: http://apps.who.int/iris/bitstream/10665/44692/1/9789241502221_eng.pdf

5. Furuta M, Sandall J, Bick D. Women's perceptions and experiences of severe maternal morbidity - A synthesis of qualitative studies using a meta-ethnographic approach. Midwifery[Internet]. 2014[cited 2016 Nov 20];30(2):158-69. Available from: http://dx.doi. org/10.1016/j.midw.2013.09.001

6. Garthus-Niegel S, von Soest T, Vollrath ME, Eberhard-Gran M. The impact of subjective birth experiences on post-traumatic stress symptoms: a longitudinal study. Arch Womens Ment Health [Internet]. 2013[cited 2016 Nov 20];16:1-10. Available from: http:// dx.doi.org/10.1007/s00737-012-0301-3

7. American Psychiatric Association. Manual diagnóstico e estatístico de transtornos mentais: DSM-5. $5^{\text {th }}$ ed. Porto Alegre: Artmed; 2014.

8. Reblin M, Uchino BN. Social and Emotional Support and its Implication for Health. Curr Opin Psychiatry[Internet]. 2008[cited 2016 Dec 15];21(2):201-5. Available from: http://dx.doi.org/10.1097/YCO.0b013e3282f3ad89

9. Cheryl A. Impact of traumatic birth experience on Latina adolescent mothers. Issues Ment Health Nurs[Internet]. $2010[$ cited 2016 Nov 15];31:700-7. Available from: http://dx.doi.org/10.3109/01612840.2010.518784

10. Matsukura TS, Marturano EM, Oishi J. O Questionário de Suporte Social (SSQ): estudos da adaptação para o português. Rev LatinoAm Enfermagem[Internet]. 2002;10(5):675-81. Available from: http://dx.doi.org/10.1590/S0104-11692002000500008

11. Vaux A. Social Support: theory, research and intervention[Internet]. New York: Praeger; 1988[cited 2017 Feb 24]. Available from: https://doi.org/10.1176/ps.41.4.460

12. Sarason IG, Levine HM, Basham RB, Saranson BR. Assessing social support: The Social Support Questionnaire. J Personal Social Psychol[Internet]. 1983[cited 2017 Feb 24];44(1):127-39. Available from: http://psycnet.apa.org/record/1983-22463-001

13. Heitzman CA, Kaplan RM. Assessment of methods for measuring Social Support. Health Psychol[Internet]. 1988 [cited 2017 Feb 24];7(1):75-109. Available from: https://www.ncbi.nlm.nih.gov/pubmed/3277843

14. Cohen S. Wills TA. Stress, Social Support, and the Buffering Hypothesis. Psychol Bull[Internet]. 1985[cited 2017 Feb 24];98(2):31057. Available from: http://psycnet.apa.org/record/1986-01119-001

15. Castro R, Campero L, Hernández B. La investigación sobre apoyo social en salud: situación actual y nuevos desafíos. Rev Saúde Pública[Internet]. 1997[cited 2017 Feb 24];31(4):425-35. Available from: http://www.scielo.br/pdf/rsp/v31n4/2277.pdf

16. Silva ACO, Nardi AE, Horowitz M. Versão brasileira da Impact of Event Scale (IES): tradução e adaptação transcultural. Rev Psiquiatr[Internet]. 2010[cited 2017 Feb 23];32(3):86-93. Available from: http://dx.doi.org/10.1590/S0101-81082010000300005

17. Ayers S. Delivery as a traumatic event: Prevalence, risk factors and treatment for postnatal posttraumatic stress disorder. Clin Obstet Gynecol[Internet]. 2004[cited 2016 Oct 18];47:552-67. Available from: http://dx.doi.org/10.1097/01.grf.0000129919.00756.9c

18. Stephen J. Psychometric evaluation of Horowitz's Impact of Event Scale: a review. J Trauma Stress[Internet]. 2002 [cited 2016 Nov 27];13:101-13. Available from: http://dx.doi.org/10.1023/A:1007777032063

19. Coffey SF, Gudmundsdottir B, Beck JG, Palyo SA, Miller L. Screening for PTSD in motor vehicle accident survivors using the PSSSR and IES. J Trauma Stress[Internet] 2006[cited 2017 Jan 15];19(1):119-28. Available from: http://dx.doi.org/10.1002/jts.20106

20. Weiss DSMCR. Impact of Event Scale (IES-R). In: Wilson T, Keane T, (Eds.). The Impact of event Scale - Revised: assessing psychological trauma and PTSD. New York: Guilford Press; 1997. p. 399-411.

21. Brunet A, St-Hilaire A, Jehel L, King S. Validation of a French version of the impact of event scale-revised. Can J Psychiatry[lnternet]. 2003[cited 2017 Oct 12];48:56-61. Available from: https://www.ncbi.nlm.nih.gov/pubmed/12635566

22. Caiuby AVS, Lacerda SS, Quintana MI, Torii TS, Andreoli SB. Adaptação transcultural da versão brasileira da Escala do Impacto do Evento - Revisada (IES-R). Cad Saúde Pública[Internet]. 2012[cited 2017 Oct 12];28(3):597-603. Available from: http://dx.doi. org/10.1590/S0102-311X2012000300019

23. Sveen J, Low A, Dyster-Aas J, Ekselius L, Willebrand M, Gerdin B. Validation of a Swedish version of the Impact of Event ScaleRevised (IES-R) in patients with burns. J Anxiety Disord[Internet]. 2010[cited 2017 Oct 12];24:618-22. Available from: https:// linkinghub.elsevier.com/retrieve/pii/S0887-6185(10)00083-6 
24. Gray CD, Kinnear PR. IBM SPSS statistics 19 made simple. Psychology Press; 2012.

25. Pacheco AJC, Katz L, Souza ASR, Amorim MMR. Factors associated with severe maternal morbidity and near miss in the São Francisco Valley, Brazil: a retrospective, cohort study. BMC Pregnancy Childbirth[Internet] 2014[cited 2016 Oct 17];14:91. Available from: http://dx.doi.org10.1186/1471-2393-14-91

26. Morse ML, Fonseca SC, Gottgtroy CL, Waldmann CS, Gueller E. Morbidade Materna Grave e Near Misses em Hospital de Referência Regional. Rev Bras Epidemio|[Internet]. 2011[cited 2017 Feb 23];14(2):310-22. Available from: http://dx.doi.org/10.1590/ S1415-790X2011000200012

27. Santana DS, Cecatti JG, Surita FG, Silveira C, Costa ML, Souza JP, et al. Twin Pregnancy and Severe Maternal Outcomes. The World Health Organization Multicountry Survey on Maternal and Newborn Health. Obstet Gynecol [Internet]. 2016 [cited 2016 Dec 20];127(4). Available from: http://dx.doi.org/10.1097/AOG.0000000000001338

28. Souza JP, Cecatti JG, Parpinelli MA, Krupa F, Osis MJ. An emerging "maternal near-miss syndrome": narratives of women who almost died during pregnancy and childbirth. Birth[Internet]. 2009[cited 2017 Jan10];36:149-58. Available from: http://dx.doi. org/10.1111/j.1523-536X.2009.00313.x

29. Silva DVR, Silveira MFA, Gomes-Sponholz FA. Experiences with severe maternal morbidity: a qualitative study on the perception of women. Rev Bras Enferm[Internet]. 2016[cited 2017 Jan10];69(4):618-24. Available from: http://dx.doi.org/10.1590/0034-7167.2016690407i

30. Furuta M, Sandall J, Cooper D, Debra B. The relationship between severe maternal morbidity and psychological health symptoms at 6-8 weeks postpartum: a prospective cohort study in one English maternity unit. BMC Pregnancy Childbirth[Internet]. 2014[cited 2017 Jan 10];14:133. Available from: http://dx.doi.org/10.1186/1471-2393-14-133

31. Shaban Z, Dolatian M, Shams J, Alavi-Majd H, Mahmoodi Z, Sajjadi H. Post-Traumatic Stress Disorder (PTSD) Following Childbirth: Prevalence and Contributing Factors. Iran Red Crescent Med J[Internet]. 2013[cited 2016 Dec 15];15(3). Available from: http:// dx.doi.org/10.1080/14767050902801686

32. Forray A, Mayes LC, Magriples U, Epperson CN. Prevalence of post-traumatic stress disorder in pregnant women with prior pregnancy complications. J Matern Fetal Neonatal Med[Internet]. 2009[cited 2016 Dec 24];22(6):522-27. Available from: http:// dx.doi.org/10.1080/14767050902801686

33. Ozbay F, Johnson CD, Dimoulas E, Morgan CA, Charney D, Southwick S. Social Support and Resilience to Stress From Neurobiology to Clinical Practice. Psychiatry[Internet]. 2007[cited 2016 Dec 20];4(5):35-40. Available from: https://www.ncbi.nlm.nih.gov/ pubmed/20806028 